\title{
Evaluation of effects of Mycoplasma mastitis on milk composition in dairy cattle from South Australia
}

\author{
Abd Al-Bar Al-Farha ${ }^{1,2^{*}}$, Farhid Hemmatzadeh ${ }^{1,3}$, Manouchehr Khazandi ${ }^{1,3}$, Andrew Hoare ${ }^{5}$ and Kiro Petrovski ${ }^{1,3,4}$
}

\begin{abstract}
Background: Mycoplasma mastitis is increasingly posing significant impact on dairy industry. Although the effects of major conventional mastitis pathogens on milk components has been widely addressed in the literature, limited data on the effects of different Mycoplasma and Acholeplasma spp. on milk quality and quantity is available. The aim of this study was to determine the casual relationship of Mycoplasma spp. and A. laidlawii to mastitis and compare them to subclinical mastitis caused by conventional mastitis pathogens from a single dairy herd in South Australia; Mycoplasma spp. and A. laidlawii were detected using PCR applied directly to milk samples. The herd had mastitis problem with high somatic cell count and low response rate to conventional antimicrobial therapy. A total of 288 cow-level milk samples were collected aseptically and used in this study.

Results: Conventional culture showed a predominance of coagulase-negative staphylococci, followed by coagulasepositive staphylococci, Streptococcus spp., Enterococcus spp., E. coli, and Klebsiella spp. PCR results showed a high prevalence of mycoplasmas (76.7\%), including A. laidlawii (10.8\%), M. bovis (6.2\%), M. bovirhinis (5.6\%), M. arginini (2\%), and (52.1\%) of cows were co-infected with two or more Mycoplasma and Acholeplasma species. Mycoplasma co-infection significantly increased somatic cell counts (SCC) similar to conventional mastitis pathogens and compared to non-infected cows with 389.3, 550.3 and 67.3 respectively; and decreased the milk yield with 29.0, 29.9 and 34.4 I, respectively. Mycoplasma co-infection caused significant increase in protein percentage, and significant decrease in fat percentage and total milk solids, similar to other conventional mastitis pathogens. In contrast, changes in milk composition and yield caused by various individual Mycoplasma species were non-significant.

Conclusions: Mycoplasma mastitis had on-farm economic consequences similar to common conventional mastitis pathogens. Results of our study indicate that co-infection Mycoplasma mastitis caused similar effect on milk composition to other mastitis pathogens and we hope these findings raise the awareness of the importance of their detection on routine diagnostic panels.
\end{abstract}

Keywords: Mycoplasma, Mastitis, Dairy cattle, Milk composition, Somatic cell count (SCC)

\section{Background}

The genus Mycoplasma belongs to the class Mollicutes and is responsible for many diseases in cattle, including respiratory disorders, arthritis, otitis media, and mastitis [12, 23, 41]. Mycoplasma mastitis is highly resilient to antimicrobial therapy and can be easily missed during laboratory culture and susceptibility testing diagnostic

\footnotetext{
* Correspondence: abdal-barahmednoori.al-farha@adelaide.edu.au ${ }^{1}$ School of Animal and Veterinary Sciences, The University of Adelaide, Roseworthy, South Australia 5371, Australia

${ }^{2}$ Northern Technical University, Technical Foundation, Mosul, Iraq

Full list of author information is available at the end of the article
}

panels [25]. Among the 200 species of Mycoplasma discovered to date, several have been reported to be involved in bovine mastitis such as $M$. bovis, $M$. bovigenitalium, $M$. californium, M. bovirhinis, M. arginini, M. dispar, $M$. canadense, M. bovoculi, and Mycoplasma spp. bovine groups 7 and F-38 [13]. Some studies have also indicated that Acholeplasma spp. can be a milk contaminant or non-pathogenic saprophyte [5, 27]. However, others have reported isolation of $A$. laidlawii from clinical and subclinical cases of bovine mastitis, suggesting a causal relationship [31, 61, 63]. 
In dairy herds, mycoplasmas can cause clinical, subclinical or chronic mastitis [16]. M. bovis is considered the most common pathogen among mycoplasmas [14]. The possibility of isolating Acholeplasma spp. from mastitis cases is not excluded $[8,31,61,63]$. The incubation period of Mycoplasma mastitis is 10-14 days [48], and shedding of the causative pathogen may occur during this period contributing to the spread of bacteria. Economic consequences of Mycoplasma mastitis in cattle are due to decreased milk production, cost of implementing control procedures, and cost of diagnosis and treatment [39]. For instance, the cost of $M$. bovis infection in cattle is more than US\$140 million annually in the United States, and even higher losses have been reported in Europe [2].

Bacteriological culture of mycoplasmas from milk samples was once the most common method of detection. However, this method is relatively slow often taking one to 2 weeks with potential non-growth of these bacteria due to their fastidious culture requirements [45, 51], Mycoplasma mastitis is usually excluded from general mastitis screening tests due to its special growth requirements and time delay [30]. Similarly, serological detection method is timeconsuming as antibody formation requires approximately 2 weeks [26]. Furthermore, there is a variation in the growth requirements of different species of Mycoplasma [20] which consequently affects disease detection, particularly when Mycoplasma co-infection occurs. However, most mastitis diagnostic investigations focus on the predominant species of mycoplasma associated with infection, M. bovis, and disregard other causative Mollicutes [52]. Studies of clinical Mycoplasma co-infection also deserve more attention, especially for epidemiological and treatment investigations. Therefore, development of a rapid and reliable screening diagnostic method is required which will be capable in distinguishing between different mycoplasma genera and species.

The association between Mycoplasma mastitis, individual somatic cell count (SCC) and milk yield also requires clarification. The association between conventional pathogens causing mastitis, such as Streptococcus and Staphylococcus spp., and elevated SCC has been previously reported [10, 19]. Mycoplasma mastitis can also affect SCC patterns [32, 47]. A marked decrease in milk production has been estimated particularly from mastitis caused by S. agalactiae, Mycoplasma spp. and Pasteurella spp. [62]. However, the effect of Mycoplasma mastitis compared to conventional bacterial pathogens on other milk composition has yet to be evaluated. Furthermore, the pathogenicity of each individual Mycoplasma spp., either as a single or co-infection, needs to be explored.

This study had two aims. The first aim of this study was to determine the effects of different Mycoplasma spp. and A. laidlawii compared to conventional mastitis pathogens on milk yield and other milk components in cattle with high SCC (subclinical mastitis) from a single dairy herd in South Australia with low response rate to conventional antimicrobial therapy. The second aim was to identify Mycoplasma spp. and A. laidlawii using novel PCR applied directly to milk samples.

\section{Methods}

\section{Sample collection}

Milk samples were collected aseptically once from each individual cow from a single commercial dairy farm near Mount Gambier, South Australia. This farm had a history of repeated failure of mastitis treatment with high SCC. Samples originated from cows aged 2-10 years in the hospital mob or main milking mob if they had a high SCC. Composite milk samples were collected aseptically in sterile $50 \mathrm{~mL}$ tubes from each functional quarter of individual cows $(n=288)$. Samples were kept on ice and were sent immediately to the PC2 laboratory at The University of Adelaide, Roseworthy Campus. In the laboratory, milk samples were subjected to conventional microbial culture using $10 \mu \mathrm{L}$ aliquots according to National Mastitis Council guidelines [24]. All samples were then frozen at $-20{ }^{\circ} \mathrm{C}$ for further analysis.

\section{Milk analysis data}

A database of individual cow yield production parameters (yield, total milk solids, fat and protein percentage) and SCC for sampled and non-sampled cows (the rest of the herd's cows that have also high and low SCC) was obtained from herd testing information for the 4 herd tests closest to the sampling points $(n=7609$ cow data points). SCC was performed for each milk sample using a FOSS Fossomatic 5000 (Hillerød, Denmark), and instrumental milk components assay by a commercial laboratory (NHIS, Cohuna, VIC, Australia).

\section{DNA extraction}

After thawing milk at ambient temperature, $2 \mathrm{~mL}$ of each sample was centrifuged at $8000 X \mathrm{~g}$ for $20 \mathrm{~min}$ to remove supernatant fat and excess liquid. DNA extraction was performed directly from milk using the QIAmp DNA extraction kit (Qiagen, Germany) according to the manufacturer's instructions with minor modifications. In order to increase the DNA yield, a much larger milk sample $(1 \mathrm{~mL})$ was centrifuged at $5000 X \mathrm{~g}$ for $30 \mathrm{~min}$ and the lipid layer removed. Genomic DNA concentration was measured using Nanodrop 1000c (Thermofisher Scientific Inc., Waltham, MA, USA) and stored at $-20{ }^{\circ} \mathrm{C}$ until further use.

\section{PCR probes and protocol}

A modified PCR protocol using four pairs of speciesspecific primers previously published elsewhere was developed (Table 1). In-vitro amplification of DNA to 
Table 1 Oligonucleotides primers for detection of mycoplasmas and A. laidlawii identified by conventional PCR

\begin{tabular}{|c|c|c|c|c|c|}
\hline Primers & Sequencing 5'-3' & Species & Targets & Amplicon size (bp) & Ref \\
\hline $\mathrm{Mb}-\mathrm{F}$ & CTTGGATCAGTGGCTTCATTAGC & M.bovis & VspA gene & 400 & [1] \\
\hline$M b-R$ & GTCATCATGCGGAATTCTTGGGT & & & & \\
\hline $\operatorname{Arg}-\mathrm{F}$ & AGAGTTTGATCCTGGCTCAGGA & M. arginini & 16S rRNA gene & 449 & [11] \\
\hline Arg-R & TCAACCAGGTGTTCTTTCCC & & & & \\
\hline Mbv-F & GCTGATAGAGAGGTCTATCG & M. bovirhinis & 16S rRNA gene & 316 & [34] \\
\hline$M b v-R$ & ATTACTCGGGCAGTCTCC & & & & \\
\hline Acho-F & AGCCGGACTGAGAGGTCTAC & A. lailawii & 16S rRNA gene & 505 & [11] \\
\hline Acho-R & TAATCCTGTTTGCTCCCCAC & & & & \\
\hline
\end{tabular}

detect Mycoplasma and Acholeplasma spp. was carried out in $25 \mu \mathrm{L}$ volumes consisting of $0.25 \mu \mathrm{L}$ Taq DNA polymerase, $5 \mu \mathrm{L}$ of $5 \times$ reaction buffer (Biolab, UK), $1 \mu \mathrm{L}$ forward primer, $1 \mu \mathrm{L}$ reverse primer, $1 \mu \mathrm{L}$ of template DNA and $16.75 \mu \mathrm{L}$ of DEPC-treated water. Amplifications were performed for 35 PCR cycles using the $\mathrm{T}_{100^{\mathrm{rm}}}$ Thermal Cycler (Biorad Australia) and consisted of preheating activation for $5 \mathrm{~min}$ at $95^{\circ} \mathrm{C}$, denaturation at $95{ }^{\circ} \mathrm{C}$ for $30 \mathrm{~s}$, and annealing at $60^{\circ} \mathrm{C}$ for $M$. bovis and A. laidlawii, $55{ }^{\circ} \mathrm{C}$ for $M$. arginini and $64{ }^{\circ} \mathrm{C}$ for $M$. bovirhinis. The final extension step was performed at $72{ }^{\circ} \mathrm{C}$ for $10 \mathrm{~min}$. The PCR products were subjected to electrophoresis in $1.5 \%$ agarose gels and visualised by staining with Gel Red.

\section{Statistical analysis}

For statistical analysis individual cows were grouped as follows:

a. Bacteriologically analysed milk samples (all with SCC of $>250,000$ cells $/ \mathrm{mL}$ and assumed to have subclinical mastitis, $n=288$ ): which were positive for pure $M$. bovis detection (GROUP 1, $n=11$ ); positive for pure A. laidlawi detection (GROUP 2, $\mathrm{n}=28$ ); positive for pure $M$. bovirhinis detection (GROUP $3, n=13$ ); positive for pure $M$. arginini detection $(n=6)$; positive for Mycoplasma co-infection by two or more detected species (GROUP 4, $n=119$ ); positive for conventional mastitis pathogens and Mycoplasma negative (GROUP 5, $n=58$ ), and cows with positive Mycoplasma/Acholeplasma detection and positive on conventional mastitis culture (GROUP 6, $n=53$ ).

b. Milk samples not bacteriologically analysed: cows with SCC of $>250,000$ cells $/ \mathrm{mL}$ - assumed to have subclinical mastitis but not sampled (GROUP 7, $n=1146$ ); and cows with SCC of $\leq 250,000$ cells $/ \mathrm{mL}$ assumed to be non-affected by subclinical mastitis 'healthy cows', (GROUP 8, $n=6181$ ).

Statistical analysis software (SAS) version 9.4 (Cary Inc., USA) was used to analyse data.
For assessment of the effect of subclinical mastitis (1) or no subclinical mastitis (0) on SCC, herd test data were log transformed (somatic cell score; SCS). Due to the small number of positive detections $(n=6)$, the effect of $M$. arginini on milk composition and yield was not estimated.

The effect of subclinical mastitis on the test-day geometric mean of SCC was estimated using LOGISTIC REGRESSION in PROC GLIMMIX of SAS. The values obtained by modelling for the SCS were back-transformed to obtain the geometric mean of SCC. The effect of subclinical mastitis on test-day milk production parameters (yield, fat, protein and total milk solids) with pathogen as fixed effect and a cow as a random effect, was estimated using ANOVA in PROC MIXED of SAS. The effect of age and stage of production (i.e. days in milk) were not included in the final analysis as the preliminary model demonstrated no significant effect. A statistical difference of $P<0.05$ was set as significant and $P<0.001$ was highly significant.

\section{Results}

Results showed that 221 of the 288 milk samples (76.7\%) collected from the dairy farm were positive for Mycoplasma spp. and A. laidlawii. Among these, Mycoplasma coinfection with two or more genera/species predominated (52.1\%), followed by single infections with $A$. laidlawii (10.8\%), M. bovis (6.2\%), M. bovirhinis (5.6\%), and $M$. arginini (2\%) (Table 2). Agarose gel electrophoresis for PCR products revealed amplicon sizes stated in (Table 1). Conventional culture for all milk samples, independently of Mollucites isolation, showed a predominance of coagulasenegative staphylococci (CoNS) (12.2\%), and relatively low occurrence of coagulase-positive staphylococci (CoPS) (2.4\%), Streptococcus spp. (2.1\%), Enterococcus spp. (1.7\%), E. coli (1.4\%), and Klebsiella spp. (0.4\%) (Table 3).

Significant difference in test-day SCC was detected between groups (Mycoplasma co-infection; GROUP 4, conventional mastitis pathogens; GROUP 5, mycoplasmas and other pathogens; GROUP 6, and not tested high SCC cows; GROUP 7) and assumed healthy cows (low SCC; 
Table 2 Distribution of Mycoplasma spp. detected by PCR for various conventional mastitis culture as detected directly from milk samples

\begin{tabular}{|c|c|c|c|c|c|c|c|}
\hline \multirow{2}{*}{$\begin{array}{l}\text { Conventional } \\
\text { mastitis culture }\end{array}$} & \multicolumn{6}{|c|}{ Mycoplasma detected spp. } & \multirow[t]{2}{*}{ Total } \\
\hline & A. laidlawii & M. bovis & M. bovirhinis & M. arginini & Mixed & Negative & \\
\hline Negative (\%) & $\begin{array}{l}28 \\
(9.7)\end{array}$ & $\begin{array}{l}11 \\
(3.8)\end{array}$ & $\begin{array}{l}13 \\
(4.5)\end{array}$ & $\begin{array}{l}3 \\
(1)\end{array}$ & $\begin{array}{l}119 \\
(41.3)\end{array}$ & $\begin{array}{l}56 \\
(19.4)\end{array}$ & $\begin{array}{l}230 \\
(79.9)\end{array}$ \\
\hline Positive (\%) & $\begin{array}{l}3 \\
(1)\end{array}$ & $\begin{array}{l}7 \\
(2.4)\end{array}$ & $\begin{array}{l}3 \\
(1)\end{array}$ & $\begin{array}{l}3 \\
(1)\end{array}$ & $\begin{array}{l}31 \\
(10.76)\end{array}$ & $\begin{array}{l}11 \\
(3.8)\end{array}$ & $\begin{array}{l}58 \\
(20.1)\end{array}$ \\
\hline $\begin{array}{l}\text { Total } \\
(\%)\end{array}$ & $\begin{array}{l}31 \\
(10.8)\end{array}$ & $\begin{array}{l}18 \\
(6.2)\end{array}$ & $\begin{array}{l}16 \\
(5.6)\end{array}$ & $\begin{array}{l}6 \\
(2)\end{array}$ & $\begin{array}{l}150 \\
(52.1)\end{array}$ & $\begin{array}{l}67 \\
(23.2)\end{array}$ & $\begin{array}{l}288 \\
(100)\end{array}$ \\
\hline
\end{tabular}

GROUP 8; $P<0.001)$ with $389.32,550.26,611,960.7$ and $67.33 \mathrm{SCCx} 10^{3}$ cell $/ \mathrm{mL}$ respectively. The Mycoplasma co-infected cows (GROUP 4) showed significant difference of SCC from assumed healthy cows (GROUP 8) at 376.15 $\mathrm{SCC} 10^{3} \mathrm{cell} / \mathrm{mL}(P \leq 0.05)$. However, no significant difference was observed between cows infected with $M$. bovis (GROUP 1) and A. laidlawii (GROUP 2) in comparison with assumed healthy cows (GROUP 8) with 255.09 and $216.14, \mathrm{SCC} x 10^{3}$ cell $/ \mathrm{mL}$ respectively $(P>0.05)$. Correspondingly, test day milk yield was similarly affected significantly in Mycoplasma co-infection (GROUP 4), conventional mastitis pathogens (GROUP 5) and mycoplasmas and conventional pathogens (GROUP 6) in comparison with assumed healthy cows (GROUP 8) with 29.0, 29.9, 27.9 and 34.41 , respectively $(P<0.001)$. In contrast, milk yield did not decline significantly in cows infected with $M$. bovis (GROUP 1), A. laidlawii (GROUP 2), or M. bovirhinis (GROUP 3) with 32.4, 32.4 and $30.0 \mathrm{l} /$ day, respectively $(P>0.05)$.

Fat percentage was significantly decreased in cows co-infected with Mycoplasma (GROUP 4) with 3.1\% $(P<0.01)$, while no differences were observed in all other tested groups with 3.4, 3.3, 3.3, 3.2 and 3.3\% for groups M. bovis (GROUP 1), A. laidlawii (GROUP 2), $M$. bovirhinis (GROUP 3), conventional mastitis pathogens (GROUP 5) and mixed Mycoplasma/Acholeplasma and conventional mastitis culture (GROUP 6) respectively $(P>0.05)$. Protein percentage increased significantly in cows

Table 3 Prevalence of non-Mycoplasma bacteria isolated by conventional mastitis culture from 288 milk samples collected purposively to identify Mycoplasma infections

\begin{tabular}{ll}
\hline Species. & Frequency (\%) \\
\hline CoNS & $35(12.2)$ \\
CoPS & $7(2.4)$ \\
Streptococcus & $6(2.1)$ \\
Enterococcus & $5(1.7)$ \\
E.coli & $4(1.4)$ \\
Klebsiella & $1(0.4)$ \\
ND & $230(79.86)$ \\
Total & $288(100 \%)$ \\
\hline
\end{tabular}

with Mycoplasma co-infection (GROUP 4), conventional mastitis pathogens (GROUP 5), mixed Mycoplasma/Acholeplasma and conventional mastitis culture (GROUP 6) and non-tested high SCC (GROUP 7) in comparison with cows assumed to be healthy (GROUP 8) with 3.4, 3.3, 3.4, 3.4 and $3.3 \%$, respectively $(P<0.05)$, while other Mycoplasma groups showed no differences being 3.4, 3.4 and 3.3\% for GROUPs s 1,2 and 3 respectively $(P>0.05)$. In comparison, total milk solids decreased significantly in GROUPs 4, 5, 6 and 7 in comparison to GROUP 8 with 1.8, 1.9, 1.8, 2.0 and $2.2 \%$, respectively $(P<0.001)$. However, there were no differences in total milk solids for GROUPs 1,2 and 3 with $2.1,2.1$ and $2.0 \%$, respectively $(\mathrm{P}>0.05)$ (Table 4$)$.

\section{Discussion}

Results showed a high prevalence of Mycoplasma and Acoleplasma species isolated from the purposive sampled cows. In addition, Mycoplasma co-infection significantly changed milk quality and quantity, similarly to other mastitis pathogens. Details on the results of culture and PCR, including test characteristics, were not subject of this study and are not further detailed.

The study farm had a history of mastitis treatment failure and high SCC. The long persistence of this problem may be due to the variety of transmission methods, such as via direct contact, milking machines and other fomites [29]. Intermittent shedding of the pathogen from cows suffering chronic mastitis may be another important reason for the relatively high prevalence of Mycoplasma mastitis in the studied herd. Chronic mastitis results from the capability of Mycoplasma spp. to form multiple micro-abscesses within the infected mammary gland [28]. Due to the high occurrence of mastitis, the studied farm is not representative of the South Australian dairy cattle population. As the primary objective of this study was not to carry out an epidemiological investigation, but to purposively sample and collect a significant number of isolates for research, the validity of the study is not decreased. In addition, study results may raise awareness of the importance of Mycoplasma mastitis to the dairy industry. In order to establish the prevalence of this disease in Australia, further attempts in affected herds using methodology similar to that described in this study are required. It is possible that the PCR technique used in 
Table 4 The mean values ( \pm SE) of SCC, milk yield, milk fat, protein and total solids for dairy cattle infected with Mycoplasma and other mastitis pathogens (in individual cow-testing points)

\begin{tabular}{|c|c|c|c|c|c|c|c|c|}
\hline & & Group & Frequency & $\begin{array}{l}\text { Milk yield } \\
\text { (litre/day) }\end{array}$ & $\begin{array}{l}\text { Fat } \\
\text { percentage }\end{array}$ & $\begin{array}{l}\text { Protein } \\
\text { percentage }\end{array}$ & $\begin{array}{l}\text { Total milk } \\
\text { solids }\end{array}$ & $\begin{array}{l}\mathrm{SCC} \times 10^{3} \\
\text { cell/mL }\end{array}$ \\
\hline \multirow[t]{6}{*}{ Tested } & 1 & Mycoplasma bovis & 11 & $32.4 \pm 3.73$ & $3.4 \pm 0.26$ & $3.4 \pm 0.09$ & $2.1 \pm 0.20$ & $255.1 \pm 140.07$ \\
\hline & 2 & Acholeplasma laidlawii & 28 & $32.4 \pm 2.33$ & $3.3 \pm 0.16$ & $3.4 \pm 0.06$ & $2.1 \pm 0.13$ & $216.1 \pm 87.79$ \\
\hline & 3 & M. bovirhinis & 13 & $30.0 \pm 3.43^{\mathrm{a}}$ & $3.3 \pm 0.24$ & $3.3 \pm 0.09$ & $2.0 \pm 0.19$ & $376.2 \pm 128.85^{\circ}$ \\
\hline & 4 & Mycoplasma co-infection & 119 & $29.0 \pm 1.13^{\mathrm{A}}$ & $3.1 \pm 0.08^{\mathrm{a}}$ & $3.4 \pm 0.03^{\mathrm{A}}$ & $1.9 \pm 0.06^{\mathrm{A}}$ & $389.3 \pm 42.58^{\mathrm{A}}$ \\
\hline & 5 & Conventional mastitis pathogens & 58 & $29.9 \pm 1.57^{\mathrm{a}}$ & $3.2 \pm 0.11$ & $3.3 \pm 0.04^{\mathrm{a}}$ & $1.9 \pm 0.09^{A}$ & $550.3 \pm 59.00^{\mathrm{A}}$ \\
\hline & 6 & Mycoplasmas and conventional pathogens & 53 & $27.9 \pm 1.79^{\mathrm{A}}$ & $3.3 \pm 0.12$ & $3.4 \pm 0.04^{\mathrm{A}}$ & $1.8 \pm 0.11^{\mathrm{A}}$ & $611 \pm 12.08^{\mathrm{A}}$ \\
\hline Total & & & $282(3.7 \%)$ & & & & & \\
\hline \multirow[t]{2}{*}{ Non tested } & 7 & High SCC & 1146 & $29.2 \pm 0.36^{\mathrm{A}}$ & $3.6 \pm 0.02^{A}$ & $3.4 \pm 0.01^{\mathrm{A}}$ & $2.0 \pm 0.02^{A}$ & $960.7 \pm 13.72^{A}$ \\
\hline & 8 & Low SCC & 6181 & $34.4 \pm 0.15$ & $3.4 \pm 0.01$ & $3.3 \pm 0.00$ & $2.2 \pm 0.01$ & $67.3 \pm 5.90$ \\
\hline Total & & & 7327 (96.3\%) & & & & & \\
\hline
\end{tabular}

Lower case superscripts indicate statistical difference within column of $P<0.05$ or capital superscripts indicate statistical difference within column of $P<0.001$

this study detects foreign pieces of DNA. To ensure validity of our results we also carried out conventional culture for Mycoplasma (data not shown). Indeed, some culturenegative samples yielded positive PCR. To ensure that we were detecting Mycoplasma spp. and A. laidlawii, $16 \mathrm{~S}$ rRNA sequencing was also carried out (data not shown).

Results of this study highlight the tendency of $\mathrm{Myco-}$ plasma co-infection to cause a significant alteration in milk composition in comparison to any individual Mycoplasma spp. group. This seems to be a result of developing evidence for pathogenicity of Mycoplasma co-infection [17], and can be a reflection of the advanced stage of the disease. It is often thought that the mechanism of milk alteration is attributed to the pathogen severity, proportion of involved mammary glands alveoli, interference with blood or hormonal nourishment to these alveoli, epithelial integrity disruption, and milk decomposition due to enzymatic activity.

Differences between the effects of each individual Mycoplasma spp. and A. laidlawii on milk composition in this study is noteworthy. It has been reported worldwide that $M$. bovis is the primary contagious pathogen in bovine Mycoplasma mastitis [14, 35, 39, 43]. In our study, cows infected only with $M$. bovis (GROUP 1) showed no significant impacts on milk composition apart from the SCC. Cows in this group may have been at an early stage of the disease. In addition, the limited sample size of this group $(n=11)$ needs to be considered. However, the effect of $M$. bovis was significant when it contributed to the Mycoplasma co-infection group. Multiple Mycoplasma spp. infection tends to be more common in Mycoplasmaassociated diseases [59]. Although, some studies indicate the possibility of $A$. laidlawii being involves in mastitis cases [8, 31, 63], our data showed no effect on milk composition as an individual pathogen, being similar to common veterinary literature that establishes these bacteria as a milk contaminant $[4,27,40]$. We considered increased
SCC and decreased milk production in affected cows as a crucial factor confirming the contribution of Mycoplasma in bovine mastitis.

$M$. arginini was another species detected in this study. However, we excluded it from the comparison as an individual group due to the limited number of detection in milk samples $(n=6) . M$. arginini has been reported elsewhere with no significant impact on milk composition, but can be considered a predisposing agent to Str. dysagalactiae leading to severe mammary gland inflammation [58]. It is important to consider that $M$. arginini is associated with some diseases in human $[56,64]$. Evidence of transmission of $M$. arginini to human through bovine milk is available as it has been isolated from blood of a man with a history of milk product consumption who had eosinophilic ascites for 2 years [57]. M. bovirhinis (GROUP 3) showed remarkable effect on SCC and milk yield in our study. M. bovirhinis was first isolated in mastitis cows in England [21] and named by Leach [37]. These bacteria showed predominance to other mycoplasmas in some mastitis studies $[22,50]$. SCC can be elevated in cows inoculated experimentally with four different strains of $M$. bovirhinis causing subclinical mastitis [6]. However, the study of Brownlie et al. [6] lacks information on other milk composition changes.

Somatic cells mainly include macrophages, lymphocytes, polymorphonuclear and epithelial cells [44]. The elevation of these cells in bovine quarters reflects the possibility of infection and is the standard method to discriminate between healthy and mastitic cows $[7,42,46,54]$. The acceptable limit of individual cow SCC in raw milk in Australia has been established at 250,000 cell/mL [9]. Elevated SCC appears to be an immune response to mastitis caused by Mycoplasma, often followed by spontaneous recovery [15]. The negative correlation between high SCC and low milk production has been widely accepted for mastitis cases. In this study, low milk yield 
also appeared to be associated with positive Mycoplasma infection which in turn was consistently associated with higher SCC, confirming the economic impact of mastitis caused by Mycoplasma mastitis. This decline in milk yield can be attributed to reduction of synthesis ability of the secretory mammary tissue [53].

The role of Mycoplasma mastitis in declining milk fat percentage during mastitis has not been established as yet. For other mastitis causing pathogens, contradictory results have been stated for both elevation $[46,55]$ and depression of milk fat percentage $[3,33,53]$. The decline in fat percentage seems to be a result of leukocyte ingestion to fat globule [49] or due to a decrease in the synthesis and secretion activities of mammary glands [36]. It is also important to note that variation of fat percentage can also affected by stage of lactation, genetics, management, nutrition and hormonal changes [38]. This most likely explains the elevation of fat percentage in the non-tested high SCC (GROUP 7) in this study. Our results show that milk protein percentage can be elevated significantly during mastitis caused by Mycoplasma co-infection (GROUP 5) or other non-Mycoplasma pathogens (GROUP 6). It is generally thought that milk proteins increase during mastitis due to increases in blood albumins and immunoglobulins influx as an immune response [3, 18]. Protein percentage increases have been reported during $M$. agalactiae experimental mastitis in small ruminant [60].

Decreases in total milk solids were tested to allow farmers, practitioners and scientists who deal with mastitis to directly compare effects of Mycoplasma infection on milk yield to each other and to other mastitis pathogens. SCC are usually available only at herd testing level, while total milk solids can be detected daily by in-line milk meters on some farms. Hence, the effect of different mastitis pathogens on total milk solids tends to be more important than SCC records to the current dairy industry. We are aware that SCC are more sensitive to detecting early intramammary infections. With time, in-line SCC measures may be available on many farms, and the importance of total milk solids may not be as high as at this stage. Data on decreases of total milk solids will also allow for further research into economic effects of Mycoplasma mastitis to a particular dairy herd or to the entire dairy industry.

Effects on milk production and SCC detected in our study may vary between farms and this should be an area of future research.

\section{Conclusions}

In summary, we report bovine milk composition alteration during Mycoplasma mastitis. In addition, effects of Mycoplasma mastitis were compared with conventional mastitis pathogens. Results of our study indicate that co-infection Mycoplasma mastitis (GROUP 4) caused similar effect on milk composition to other conventional mastitis pathogens (GROUP 5), and we hope these findings raise the awareness of the importance of their detection on routine diagnostic panels. Ignoring timely detection may lead to developing Mycoplasma co-infection which may result in severe alterations in milk composition. However, roles of each individual Mycoplasma spp. in mastitis economics, and produced milk quantity and quality, needs further investigations, particularly when present as co-infections.

\section{Abbreviations \\ CoNS: Coagulase-negative staphylococci; CoPS: Coagulase-positive staphylococci; PCR: Polymerase chain reaction; SAS: Statistical analysis software; SCC: Somatic cell counts; SCS: Somatic cell scour}

\section{Acknowledgements}

The authors would like to express their special thanks to the farmer and farm staff for their cooperation and interest in the study. The technical support to this study by Ali Khazandi, Benjamin Linn, Budoor Ayoob, Chelsea Smith, Dana Thompson, Darren Trott, David Oswald, Gabe Laucke, Hannah Cohen, Ken Lee, Noor Haliza Hassan, Rhyanna Tedesco, and Taylor Urand is also appreciated. The guidance by Dr. Rick Tearle on statistical analysis is also appreciated.

\section{Funding}

The first author was partially funded by The Higher Committee for Education Development in Iraq in form of a scholarship. All field and laboratory procedures were financially supported by the University of Adelaide.

\section{Availability of data and materials}

The datasets generated during and/or analysed during the current study are available from the corresponding author on reasonable request.

\section{Authors' contributions}

AA, FH and KP participated in the study design and coordination. AA, KP, MK \& $\mathrm{AH}$ contributed to sample collection. AH contributed in herd test data collection and coordination with the farm. AA, MK and FH contributed in sample processing. AA and FH contributed in bacterial culture and PCR in the PC2 laboratory. KP performed the statistical analyses. All authors were involved in drafting the manuscript, read, corrected and approved the final manuscript.

Ethics approval and consent to participate

Not applicable. Samples were collected by field veterinary support that was dealing with the case and no Animal Ethics application was required (Australian code for the care and use of animals for scientific purposes, 8th edition, 2013).

Consent for publication

Not applicable as farm identity is not disclosed.

Competing interests

The authors declare that they have no competing interests.

\section{Publisher's Note}

Springer Nature remains neutral with regard to jurisdictional claims in published maps and institutional affiliations.

\section{Author details}

${ }^{1}$ School of Animal and Veterinary Sciences, The University of Adelaide, Roseworthy, South Australia 5371, Australia. ${ }^{2}$ Northern Technical University, Technical Foundation, Mosul, Iraq. ${ }^{3}$ Australian Centre for Antimicrobial Resistance Ecology, The University of Adelaide, Adelaide, South Australia 5000, Australia. ${ }^{4}$ Davies Centre, School of Animal and Veterinary Sciences, The University of Adelaide, Roseworthy, South Australia 5371, Australia. ${ }^{5}$ South East Vets, Mt Gambier, South Australia 5290, Australia. 
Received: 18 September 2017 Accepted: 15 November 2017 Published online: 25 November 2017

\section{References}

1. Alberti A, Addis MF, Chessa B, Cubeddu T, Profiti M, Rosati S, Ruiu A, Pittau M. Molecular and antigenic characterization of a Mycoplasma bovis strain causing an outbreak of infectious keratoconjunctivitis. J Vet Diagn Investig. 2006:18:41-51.

2. Amram E, Freed M, Khateb N, Mikula I, Blum S, Spergser J, Sharir B, Ozeri R, Harrus S, Lysnyansky I. Multiple locus variable number tandem repeat analysis of Mycoplasma bovis isolated from local and imported cattle. Vet J. 2013;197:286-90.

3. Auldist M, Hubble I. Effects of mastitis on raw milk and dairy products. Aust J Dairy Technol. 1998;53:28.

4. Boonyayatra S. Diagnosis of mycoplasma mastitis: validation and development. Washington: Washington State University; 2010.

5. Boonyayatra S, Fox LK, Gay JM, Sawant A, Besser TE. Discrimination between Mycoplasma and Acholeplasma species of bovine origin using digitonin disc diffusion assay, nisin disc diffusion assay, and conventional polymerase chain reaction. J Vet Diagn Investig. 2012;24:7-13.

6. Brownlie J, Howard C, Gourlay R. Pathogenicity of certain mycoplasma species in the bovine mammary gland. Res Vet Sci. 1976;20:261-6.

7. Carrillo-Casas EM, Miranda-Morales RE. Bovine mastitis pathogens: prevalence and effects on somatic cell count. Croatia: INTECH Open Access Publisher; 2012.

8. Counter D. A severe outbreak of bovine mastitis assoicated with Mycoplasma bovigenitalium and Acholeplasma laidlawii. Vet Rec. 1978;103:130-1.

9. DairyAustralia. Mastitis. Australia: Dairy Australia; 2014.

10. De Haas Y, Veerkamp R, Barkema H, Gröhn Y, Schukken Y. Associations between pathogen-specific cases of clinical mastitis and somatic cell count patterns. J Dairy Sci. 2004;87:95-105.

11. Dussurget O, Roulland-Dussoix D. Rapid, sensitive PCR-based detection of mycoplasmas in simulated samples of animal sera. Appl Environ Microbiol. 1994;60:953-9.

12. Foster AP, Naylor RD, Howie NM, Nicholas RA, Ayling RD. Mycoplasma bovis and otitis in dairy calves in the United Kingdom. Vet J. 2009;179:455-7.

13. Fox LK. Mycoplasma mastitis: causes, transmission, and control. Vet Clin North Am Food Anim Pract. 2012;28:225-37.

14. George LW, Divers TJ, Ducharme N, Welcome FL. Diseases of the Teats and Udder, Rebhun's diseases of dairy cattle, Second Edition ed. Missouri: Elsevier Health Sciences; 2007. p. 327-93.

15. Ghadersohi A, Hirst RG, Forbes-Faulkener J, Coelen RJ. Preliminary studies on the prevalence of Mycoplasma bovis mastitis in dairy in cattle in Australia. Vet Microbiol. 1999:65:185-94.

16. González RN, Wilson DJ. Mycoplasmal mastitis in dairy herds. Vet Clin N Am Food Anim Pract. 2003;19:199-221.

17. Gourlay RN, Thomas LH, Wyld SG. Increased severity of calf pneumonia associated with the appearance of Mycoplasma bovis in a rearing herd. Vet Rec. 1989;124:420-2.

18. Gráff M, Miko E. Analysis of mastitis in Holstein-Fresian cows and economic effects of mastitis. Agricult Manage/Lucrari Stiintifice Ser I Manage Agricol. 2015;17

19. Green M, Green L, Schukken Y, Bradley A, Peeler E, Barkema H, De Haas Y, Collis V, Medley G. Somatic cell count distributions during lactation predict clinical mastitis. J Dairy Sci. 2004;87:1256-64.

20. Hahn RG, Kenny GE. Differences in arginine requirement for growth among arginine-utilizing Mycoplasma species. J Bacteriol. 1974;117:611-8.

21. Harbourne J, Hunter D, Leach R. The isolation of Mycoplasma from bovine lungs and nasal swabs. Res Vet Sci. 1965;6:178-88.

22. Hirose K, Kawasaki Y, Kotani K, Tanaka A, Abiko K, Ogawa H. Detection of mycoplasma in mastitic milk by PCR analysis and culture method. J Vet Med Sci. 2001:63:691-3.

23. Hirose K, Kobayashi H, Ito N, Kawasaki Y, Zako M, Kotani K, Ogawa H, Sato H. Isolation of Mycoplasmas from nasal swabs of calves affected with respiratory diseases and antimicrobial susceptibility of their isolates. J Veterinary Med Ser B. 2003;50:347-51.

24. Hogan J, Gonzalez R, Harmon R, Nickerson S, Oliver S, Pankey J, Smith KL. Laboratory handbook on bovine mastitis. Madison: National Mastitis Council; 1999. p. 6-10.

25. Horwood PF, Schibrowski MI, Fowler EV, Gibson JS, Barnes TS, Mahony TJ. Is Mycoplasma bovis a missing component of the bovine respiratory disease complex in Australia? Aust Vet J. 2014;92:185-91.
26. Hotzel H, Frey J, Bashiruddin J, Sachse K. Detection and differentiation of ruminant mycoplasmas. PCR Detect Microbial Pathog. 2003;216:231-45.

27. Jasper D, Dellinger J, Rollins M, Hakanson H. Prevalence of mycoplasmal bovine mastitis in California. Am J Vet Res. 1979:40:1043-7.

28. Jasper DE. The role of Mycoplasma in bovine mastitis. J Am Vet Med Assoc. 1982:181:158-62.

29. Justice-Allen A, Trujillo J, Corbett R, Harding R, Goodell G, Wilson D. Survival and replication of Mycoplasma species in recycled bedding sand and association with mastitis on dairy farms in Utah. J Dairy Sci. 2010;93:192-202.

30. Kalogridou-Vassiliadou D. Mastitis-related pathogens in goat milk. Small Rumin Res. 1991:4:203-12.

31. Kirk JH, Glenn K, Ruiz L, Smith E. Epidemiologic analysis of Mycoplasma spp isolated from bulk-tank milk samples obtained from dairy herds that were members of a milk cooperative. J Am Vet Med Assoc. 1997;211:1036-8.

32. Kirk JH, Lauerman LH, Roberts C. Mycoplasma mastitis in dairy cows. Compend Contin Educ Pract Vet. 1994;16:541-52.

33. Kitchen BJ. Bovine mastitis: milk compositional changes and related diagnostic tests. J Dairy Res. 1981;48:167-88.

34. Kobayashi H, Hirose K, Worarach A, Paugtes P, Ito N, Morozumi T, Yamamoto K. In vitro amplification of the $16 \mathrm{~S}$ rRNA genes from Mycoplasma bovirhinis, Mycoplasma alkalescens and Mycoplasma bovigenitalium by PCR. J Vet Med Sci. 1998;60:1299-303.

35. Kunkel JR. Isolation of Mycoplasma bovis from bulk milk. Cornell Vet. 1985; 75:398-400.

36. Le Maréchal C, Thiéry R, Vautor E, Le Loir Y. Mastitis impact on technological properties of milk and quality of milk products-a review. Dairy Sci Technol. 2011;91:247-82.

37. Leach R. Comparative studies of mycoplasma of bovine origin. Ann N Y Acad Sci. 1967;143:305-16

38. Linn J. Factors affecting the composition of milk from dairy cows. Designing foods: animal product options in the marketplace. National Research Council (US) committee on technological options to improve the nutritional attributes of animal products, ed. Washington, DC: Natl. Acad. Press; 1988. p. 224.

39. Maunsell FP, Woolums AR, Francoz D, Rosenbusch RF, Step DL, Wilson DJ, Janzen ED. Mycoplasma bovis infections in cattle. J Vet Intern Med. 2011;25: $772-83$.

40. Nicholas, R., Ayling, R., McAuliffe, L., 2008. Mycoplasma diseases of ruminants. $C A B I$

41. Nicholas RA, Ayling RD. Mycoplasma bovis: disease, diagnosis, and control. Res Vet Sci. 2003;74:105-12.

42. Peters $\mathrm{M}$, Silveira I, Fischer $\mathrm{V}$. Impact of subclinical and clinical mastitis on sensitivity to pain of dairy cows. Animal. 2015;9:2024-8.

43. Pfutzner H, Busch S, Hauke H, Landsiedel U, Schimmel D, Templin G, Wehnert C. Studies of Mycoplasma mastitis in cattle. 7. Mycoplasma mastitis in 3 dairy cattle herds. Arch Exp Vet. 1979;33:685-97.

44. Pillai S, Kunze E, Sordillo L, Jayarao B. Application of differential inflammatory cell count as a tool to monitor udder health. J Dairy Sci. 2001; 84:1413-20

45. Pinnow CC, Butler JA, Sachse K, Hotzel H, Timms LL, Rosenbusch RF. Detection of Mycoplasma bovis in preservative-treated field milk samples. J Dairy Sci. 2001;84:1640-5.

46. Pyörälä S. Indicators of inflammation in the diagnosis of mastitis. Vet Res. 2003;34:565-78.

47. Radaelli E, Castiglioni V, Losa M, Benedetti V, Piccinini R, Nicholas RA, Scanziani $\mathrm{E}$, Luini M. Outbreak of bovine clinical mastitis caused by Mycoplasma bovis in a north Italian herd. Res Vet Sci. 2011;91:251-3.

48. Razin S. Methods in Mycoplasmology V1: Mycoplasma characterization. New York: Elsevier; 2012

49. Reiter B, Bramley A. Defence mechanisms of the udder and their relevance to mastitis control. Doc Int Dairy Fed. 1975;85:210-22.

50. Saad N, Hameed K. Detection of Mycoplasma species in raw milk of lactating animals in Assiut and Qena city of Egypt. Vet World. 2012:5:80-85.

51. Sachse K, Pfutzner H, Hotzel H, Demuth B, Heller M, Berthold E. Comparison of various diagnostic methods for the detection of Mycoplasma bovis. Rev Sci Tech. 1993;12:571-80

52. Schnee C, Schulsse S, Hotzel H, Ayling RD, Nicholas RA, Schubert E, Heller M, Ehricht R, Sachse K. A novel rapid DNA microarray assay enables identification of 37 Mycoplasma species and highlights multiple Mycoplasma infections. PLoS One. 2012;7:e33237.

53. Schultz L. Somatic cells in milk-physiological aspects and relationship to amount and composition of milk. J Food Prot ${ }^{\oplus}$. 1977;40:125-31. 
54. Schwarz D, Diesterbeck U, König S, Brügemann K, Schlez K, Zschöck M, Wolter W, Czerny C-P. Flow cytometric differential cell counts in milk for the evaluation of inflammatory reactions in clinically healthy and subclinically infected bovine mammary glands. J Dairy Sci. 2011;94:5033-44.

55. Shuster D, Harmon R, Jackson J, Hemken R. Suppression of milk production during endotoxin-induced mastitis. J Dairy Sci. 1991;74:3763-74.

56. Sillis M. Mycoplasma arginini-a new human zoonosis? Clin Infect Dis. 1994; 18:488.

57. Sillo P, Pinter D, Ostorhazi E, Mazan M, Wikonkal N, Ponyai K, Volokhov DV, Chizhikov VE, Szathmary S, Stipkovits L, Karpati S. Eosinophilic fasciitis associated with Mycoplasma arginini infection. J Clin Microbiol. 2012;50:1113-7.

58. Stipkovits L, Somogyi M, Asvanyi B, Toth A, Szathmary S. Short communication: role of Mycoplasma arginini in mastitis caused by streptococcus dysgalactiae. J Dairy Sci. 2013;96:1661-7.

59. Szacawa E, Niemczuk K, Dudek K, Bednarek D, Rosales R, Ayling R. Mycoplasma bovis infections and co-infections with other Mycoplasma spp. with different clinical manifestations in affected cattle herds in eastern region of Poland. Bull Vet Inst Pulawy. 2015;59:331-8.

60. Todaro M, Puleio R, Sabelli C, Scatassa M, Console A, Loria G. Determination of milk production losses in Valle del Belice sheep following experimental infection of Mycoplasma agalactiae. Small Rumin Res. 2015;123:167-72.

61. Watts JL. Etiological agents of bovine mastitis. Vet Microbiol. 1988;16:41-66.

62. Wilson DJ, Gonzalez RN, Das HH. Bovine mastitis pathogens in New York and Pennsylvania: prevalence and effects on somatic cell count and milk production. J Dairy Sci. 1997:80:2592-8.

63. Windsor HM, Windsor GD, Noordergraaf J. The growth and long term survival of Acholeplasma laidlawii in media products used in biopharmaceutical manufacturing. Biologicals. 2010;38:204-10.

64. Yechouron A, Lefebvre J, Robson HG, Rose DL, Tully JG. Fatal septicemia due to Mycoplasma arginini: a new human zoonosis. Clin Infect Dis. 1992; 15:434-8.

\section{Submit your next manuscript to BioMed Central and we will help you at every step:}

- We accept pre-submission inquiries

- Our selector tool helps you to find the most relevant journal

- We provide round the clock customer support

- Convenient online submission

- Thorough peer review

- Inclusion in PubMed and all major indexing services

- Maximum visibility for your research

Submit your manuscript at www.biomedcentral.com/submit 